\title{
THE MYSTERY OF THE VOTIC INESSIVE
}

\author{
Elena Markus ${ }^{1,2}$ and Fedor Rozhanskiy ${ }^{1,3}$ \\ ${ }^{1}$ University of Tartu, ${ }^{2}$ Institute of Linguistics $R A S$, and ${ }^{3}$ Institute \\ for Linguistic Studies RAS
}

\begin{abstract}
This paper analyzes the morphophonological structure of the inessive singular forms in Liivtšülä-Luuditsa Votic. There are no fluent speakers of this variety; the research is based on the materials recorded in 2003-2016. The inessive singular forms demonstrate variation of the weak and strong grade stems, which is very untypical for a case form. In all other morphological cases, the distribution of weak and strong stems is very stable. The variation in the inessive stem is observed both in the examples from published sources on the Votic language, and in our field materials. The acoustic research has confirmed the variation. Additionally, in the strong grade stem we find a shorter geminate stop or affricate compared to other strong grade forms (in the paper, the inessive singular is compared to the inessive plural and partitive singular). We consider several hypotheses that could explain the variation and the shorter geminate. The conducted experiments do not confirm the role of the word structure as the primary factor defining the geminate length. We suggest that both the variation of stems and the shorter geminate might result from language contact. In the neighbouring Ingrian varieties, the inessive is built from the weak grade stem. Since all the last fluent speakers of Votic knew Ingrian to some extent, the Votic and Ingrian patterns might have mixed. It is probable that originally the variation was triggered by some other factors, and the increasing role of the language contact turned it into a dominant factor in the course of the 20th century.
\end{abstract}

Keywords: inessive, morphology, morphophonology, language contact, experimental phonetics, geminate, variation, Votic

DOI: https://doi.org/10.12697/jeful.2019.10.2.07

\section{Background}

It would not be an exaggeration to say that the inessive is the most mysterious case in Votic. The main Votic grammars are surprisingly inconsistent when describing the stem in the inessive form. The most often cited grammar by Ariste (1968: 23-24) says that 
A characteristic feature of the Votic inessive is the fact that geminate stops - $k k-,-p p-,-t t-$, the geminate affricates - $t t s-$, - $t t \check{s}^{-}$, the geminate $-s s-$, and the consonant cluster - $h s$ - always are in the strong grade before this marker, e.g. verkkoza 'net (iness.)', rōppaza 'porridge (iness.)', лauttaza 'animal shed (iness.)', mettsäzä 'forest (iness.)', pittšäzä 'long, tall (iness.)', mussaza 'black (iness.)', лahseza 'child (iness.)', лuzikkaza 'spoon (iness.)', kammittsaza 'fetter (iness.)', lühzettšizä 'milking pail (iness.)'. ${ }^{1}$ However, a single stop and a single $-s$ - always has a weak grade in the inessive, e.g. orgoza 'valley (iness.)', pāza 'pot (iness.)', kravuza 'crag (iness.)', izäzä 'father (iness.)'.

The only inessive form analysed in the experimental phonetic study (Ariste 1942: 38) is nurkkaza 'corner.InEss'. In this form, $k k$ is $200 \mathrm{~ms}$ long and corresponds to a typical geminate (cf. with $k k=212 \mathrm{~ms}$ in naizikko 'woman' on the same page).

Ariste was definitely familiar with the grammar written by Tsvetkov in $1920 \mathrm{~s}^{2}$. At first glance, Tsvetkov $(2008: 16,18)$ has the same opinion about the inessive forms: "the geminated stem consonants $t, k, p$ are preserved in the illative, essive and inessive singular: $<\ldots>$ hattus $^{3}$ 'hat.INESS'". However, further in the grammar he gives examples that contradict this description (Tsvetkov 2008: 34-35, 38-39) ${ }^{4}$ : pitšäs kepis 'long.INESS stick.INESS', nervnojs tütös 'nervous.INESS girl.INESS'. Both kepis and tütos have a single consonant in the stem. Tsvetkov mentions only the stop consonants and says nothing about the affricates, but the affricate in pitšäs 'long.INESS' is not geminated. All these examples contradict the data from Ariste (1968: 23-24), where both the affricates and the stops are geminated.

The earliest Votic grammar (Ahlqvist 1856: 27-28) presents a completely different opinion. The weak grade of the stem consonant is explained as resulting from the apocope of the final vowel in the case

1 All these examples except for the last are listed in Kettunen (1930: 77).

2 The manuscript of Tsvetkov's grammar was manually copied by Paul Ariste (Tsvetkov 2008: IX).

3 Tsvetkov uses the Cyrillic transcription for Votic. We transliterate it into the Latin script according to our standards, which are close to the system used in Tsvetkov (1995) but has several differences; in particular, we transcribe the second part of diphthongs as $j$ instead of $i$

4 In his dictionary, Tsvetkov (1995) gives seven morphological forms of nouns: the nominative, genitive, partitive, illative singular, and the nominative, genitive, and partitive plural. Unfortunately, the inessive singular is not listed. 
marker. According to Ahlqvist's analysis (1856: 25, 27-28), the final vowel was dropped (he mentions explicitly the inessive and allative forms), hence the last syllable became closed. This caused the change in the quantity of the stem consonant, but later the final vowel was restored, however, the stem consonant remained the same. Thus, the Votic words kukkõ 'rooster', c 'âpppä 'grave', nättü 'cloth rag' originally had the inessive forms $k u k k \tilde{o}-z a, c$ 'âpppä-zä, nättü-zä. Due to the apocope they became kukõz, c 'âpäz, nätüz, and later (when the vowel was restored) kukõza, c 'âpäzä, nätüzä. Despite the complicated explanation, it is clear that Ahlqvist observed Votic inessive forms with single consonants in the stem. This picture is very different from the one described by Ariste (1968) a century later.

These inconsistences in the grammars cannot be explained as differences between the dialects. Although the data by Ahlqvist and by Tsvetkov refer to different varieties or even dialects ${ }^{5}$ (Kattila vs. Jõgõperä respectively), Ariste (1968) uses the data from the central Votic varieties (i.e. close to Kattila) and rather systematically comments on how it differs from the Jõgõperä dialect. Ariste (1968: 23) pays attention to the difference in the inessive marker (apocopated in Jõgõperä and with the final vowel in other varieties), but he does not mention any differences concerning the grade of the stem consonant.

Our own experience is also contradictory. While working with Votic native speakers in the Luuditsa village ${ }^{6}$ we noticed that (a) a speaker can pronounce the same inessive form either with a geminate or with a singleton, (b) while listening, it was often difficult to decide whether a single consonant or a geminate was pronounced, although in other morphological forms the contrast between a singleton and a geminate is usually very distinct. For these reasons, we decided to check the length of the consonants in the inessive forms with experimental phonetics methods.

The main goal of our study is to find out 1) how typical is the variation of the weak and strong grade stem in the inessive singular

5 The revised dialectal division of Votic is described, for example, in Markus and Rožanskij (2017).

6 The village of Luuditsa is close to Jõgõperä (about $5 \mathrm{~km}$ distance), and these varieties are rather similar to each other. The differences between these varieties are analysed in Rozhanskiy and Markus (2015). 
forms, and 2) why is it often difficult to perceptively define the grade of the consonant in these forms. We propose and check several hypotheses that could explain the observed durational effects. In particular, we investigate the potential influence of the word structure (open/closed final syllable, the correlation with the length of surrounding vowels), and possible effects of language contact.

The structure of this paper is as follows. Section 2 describes the data and methods of the research. Section 3 presents the measurements that are discussed in Section 4. Section 5 contains a short summary of the results.

\section{Data and methods}

The research is based on recordings of the Liivtšülä-Luuditsa variety $^{7}$ made by the authors in 2003-2016. There are about 200 hours of recordings from this variety in our collection. In this paper, we use the materials recorded from four native speakers:

Speaker 1: male, born in 1928 in Liivtšülä, later lived in Luuditsa; Speaker 2: female, born in 1928 in Liivtšülä, lived in Liivtšülä; Speaker 3: female, born in 1935 in Liivtšülä, later lived in Ust'-Luga settlement;

Speaker 4: male, born in 1921 in Luuditsa, later lived in St. Petersburg.

We use elicited data exclusively, because (a) this helps to diminish the effects of individuals' speech tempo, (b) it is possible to acquire more distinct pronunciations, and (c) it decreases phonetic variation.

Since we started a thorough analysis of the inessive when there were no fluent Votic speakers left, we had to use the material from our field corpus and previously recorded questionnaires, thus we had no possibility to record more data and to balance the number of pronunciations from every speaker.

7 Two neighbouring villages, Liivtšülä and Luuditsa, were merged into one village that preserved the name Luuditsa (in Russian, Lužitsy). In the 20th century, both these villages had a mixed Votic-Ingrian population, but there were more Ingrians in Luuditsa than in Liivtšülä. The Liivtšülä-Luuditsa variety belongs to the Western Votic dialect. 
For the experiment described in Section 3.1, we studied more than 850 occurrences of the inessive forms for 125 nominals that have an alternation of plosive, sibilant or affricate consonants in the stem $(p / p p, t / t t, k / k k, s / s s, t s / t t s$ or $t \check{s} / t t s)$. The test words were elicited from the four speakers as part of simple sentences. The position of the word in a sentence was not fixed.

For the experiments described in Section 3.2, we used the data from a special questionnaire that contained four case forms of more than 50 nouns and adjectives that have an alternation of plosive, sibilant or affricate singletons with the corresponding geminates. The sentences in the questionnaire provided a context that unambiguously defined the case of the noun. Since Votic is an unwritten language, the stimuli were given in Russian, and the speakers translated them into Votic. We ensured that the translation contained the target word clause-medially, since the intensity of the speech signal is typically greater in this position than at the end of the clause. It is also easier to obtain adjectives in the middle position as part of attributive constructions. Two or more pronunciations of every form were recorded from speakers 1 and 2 .

The questionnaire contained four morphological forms:

- a form with a weak grade stem (usually, the nominative plural, e.g. kepid 'stick.PL.NOM');

- two forms with a strong grade stem (usually, the partitive singular and the inessive plural, e.g. keppiä 'stick.PART', keppijz 'stick. PL.INESS');

- the inessive singular, which is the subject of this study, e.g. kepiz / keppiz 'stick.INESS'.

This set of forms allowed us to compare the length of the consonant in the inessive singular with the length of typical geminates and typical singletons. The nominative plural form has the same structure as the weak grade inessive singular, so these forms can be directly compared. The only difference is the quality of the final consonant: kepid 'stick. PL.NOM' vs. kepiz 'stick.INESS'.

It is impossible to find a form with a structure that coincides with the strong grade inessive singular and can be easily obtained for any word. For this reason, we had to use strong grade forms with a different structure: the partitive singular that ends in an open syllable and the 
inessive plural that has a closed final syllable with a diphthong ${ }^{8}$, cf. keppiä 'stick.PART' vs. keppijz 'stick.PL.INESS' vs. keppiz 'stick.INESS'.

The recordings were made with an Edirol R-09HR digital recorder and a stereo microphone (Edirol CS-15) at a 16 bit $48000 \mathrm{~Hz}$ sampling rate. The target forms were segmented and analysed in Praat (Boersma and Weenink 2018).

For a statistical analysis, a single-factor ANOVA was calculated for pairs of different morphological forms (the calculation was made in a Microsoft Excel plug-in). Based on our previous experience with Votic phonetic data, we interpret the levels of significance for $p$-value in the following way: $p>0.05$ - no difference found, $0.01<p<0.05-$ the difference is questionable, $0.001<p<0.01-$ the difference is significant, $\mathrm{p}<0.001-$ the difference is highly significant. The density curves were plotted in R Studio.

\section{Analysis}

\subsection{Variation of the weak and strong grade in the inessive singular}

The first step of the research is to estimate the degree of variation between strong and weak grade stems in the inessive forms. In this part of the analysis, we searched our corpus of elicitations for nominals that have gradation of the type "geminate vs. single plosive, sibilant or affricate consonant". Among such lexemes, 125 had the inessive forms elicited. We checked all the occurrences of the inessive forms for such words. Altogether, 861 tokens were measured ( 331 from Speaker 1, 386 from Speaker 2, 112 from Speaker 3, and 32 from Speaker 4).

Table 1 illustrates the variation that we observed with a few concrete examples. In this table, we list the durations of the alternating consonant as measured from several pronunciations of the inessive forms grouped by the speaker. We postulate that the margin between a single consonant

8 In Votic, we do not distinguish diphthongs and combinations of two vowels (see more detailed comments in Markus and Rožanskij 2017: 351-354). 
and a geminate is $120 \mathrm{~ms}^{9}$. In the table, the measurements that correspond to the geminates are highlighted with bold.

Table 1. Examples of the consonant duration (in ms) in the inessive forms

\begin{tabular}{|c|c|c|c|c|}
\hline & Speaker 1 & Speaker 2 & Speaker 3 & Speaker 4 \\
\hline $\begin{array}{l}\text { rooppâ } \\
\text { 'porridge' }\end{array}$ & $110,120, \mathbf{1 7 0}$ & 180,225 & $\begin{array}{l}70,90, \mathbf{1 5 0}, \\
\mathbf{1 6 0}\end{array}$ & \\
\hline pappi 'priest' & $\begin{array}{l}75,100 \\
\mathbf{1 3 5}, \mathbf{1 5 0}\end{array}$ & $\begin{array}{l}75,107,135,140 \\
145,155,165\end{array}$ & & \\
\hline $\begin{array}{l}\text { tikkâ } \\
\text { 'woodpecker' }\end{array}$ & $\begin{array}{l}95, \mathbf{1 5 0} \\
\mathbf{1 6 0}, \mathbf{2 0 0}\end{array}$ & $75,95, \mathbf{1 5 0}, \mathbf{1 7 0}$ & & 60 \\
\hline joršši 'ruff' & $95,105,110$ & $\begin{array}{l}100,105,120 \\
\mathbf{1 2 5}, \mathbf{1 3 0}, \mathbf{1 7 5}\end{array}$ & $\begin{array}{l}180,205 \\
300\end{array}$ & \\
\hline viлkkâ 'fork' & $\begin{array}{l}125,130 \\
135,155\end{array}$ & $\begin{array}{l}95, \mathbf{1 2 5}, \mathbf{1 6 0} \\
170,200\end{array}$ & & 100,105 \\
\hline $\begin{array}{l}\text { ugurittsâ } \\
\text { 'cucumber' }\end{array}$ & $\begin{array}{l}\text { 100, 120 } \\
\mathbf{1 3 0}, \mathbf{2 0 8}\end{array}$ & $115, \mathbf{1 5 0}$ & 55,70 & \\
\hline
\end{tabular}

Most of the analysed words in our corpus display the variation in the inessive singular similar to the examples in Table 1. We failed to find any obvious correlation between the phonetic structure of the stem and the preferred length of the consonant. Neither the number of syllables, nor the intervocalic vs. cluster context play an important role. The intrinsic duration of segments does not appear to be a factor of primary importance either. In Votic, the duration of affricates is close to the duration of plosives (see Ariste 1942: 43). We therefore suggest that the inessive forms demonstrate a free variation of the weak and strong stems, and the probable influence of other factors is of secondary importance.

Figure 1 plots the density of the consonant durations in the inessive forms for all the measured pronunciations for the four speakers.

9 This decision is based on the numerous measurements of the Votic words that we did in our previous studies. $120 \mathrm{~ms}$ is roughly the middle of the "uncertain zone" between the definite single consonants $(<100 \mathrm{~ms})$ and definite geminates $(>150 \mathrm{~ms})$, see also Markus and Rožanskij (2017: 370). 


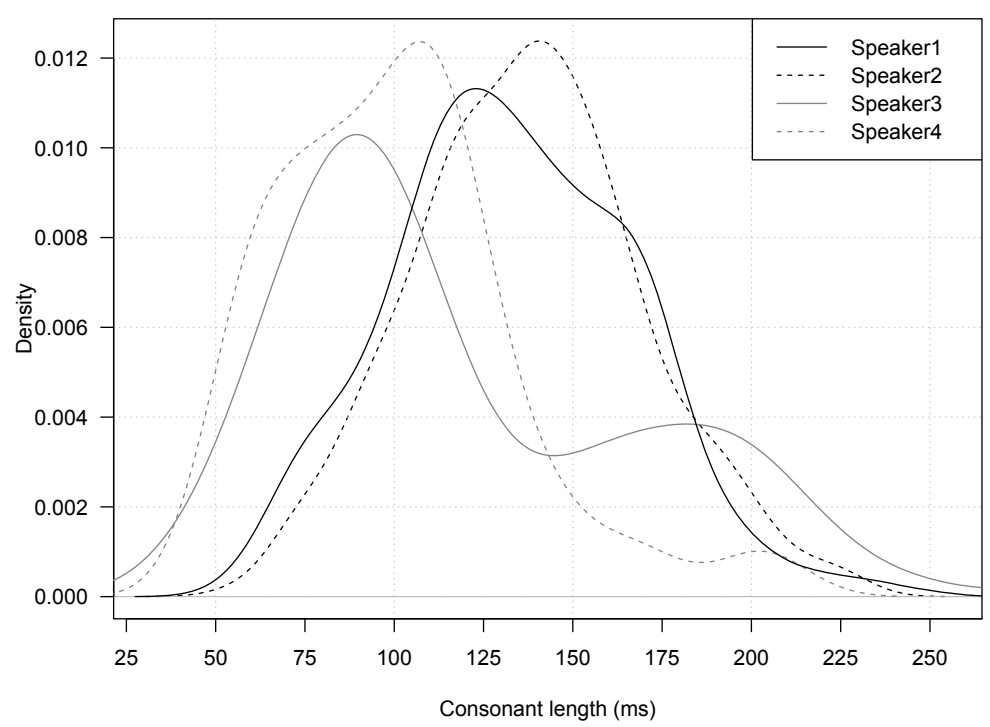

Figure 1. Density curves of the consonant durations for the four speakers.

It would be logical to suggest that we observe a variation on the morphophonological level when the same inessive singular form can be derived both from a weak and strong stem. If this was the case, we would expect two peaks on the density curves for the overall data that would correspond to two consonant types (single consonants in the weak grade stem and geminates in the strong grade stem). In fact, as seen from Figure 1, this is not the case. Apart from Speaker 3 (with a minor second peak), there are no prominent second peaks on the density curves. The dataset rather demonstrates a more or less normal distribution, and with the exception of Speaker 4 the most frequent consonant durations fall into the "uncertain zone" between single consonants and geminates (the average consonant duration is $133 \mathrm{~ms}$ for Speaker 1, $138 \mathrm{~ms}$ for Speaker 2, $122 \mathrm{~ms}$ for Speaker 3, and $100 \mathrm{~ms}$ for Speaker $4^{10}$ ).

10 The smallest average duration is observed for the only speaker who was born in the village of Luuditsa, and not Liivtšülä. However, we do not think that the weak grade inessive forms can be considered as a characteristic feature of this variety in general. In Ariste (1962: 83, 92), there are examples of the strong grade inessive forms amerikkp-zp 'America-INESS' and mettspy-z 'forest-INESS' recorded from a Luuditsa speaker. 
One could suggest that the reason why we do not observe the expected two peaks is heterogeneous data. Indeed, the pronunciations were not controlled for the position in the phrase, the speech tempo, or the context. However, the next experiment shows that similar results are achieved even if the potential effects of these factors are controlled for.

\subsection{Length of the geminate in the strong grade inessive singular}

This part of the research is based on the questionnaire described in Section 2 that was recorded from Speakers 1 and 2. For the following experiment, we chose only the inessive forms built from the strong grade stem (i.e. with stem consonants longer than $120 \mathrm{~ms}$ ). We try to understand, why it is often difficult to perceptively define the grade of the consonant in these forms, by comparing the consonant duration in the inessive singular forms with the duration of typical geminates (measured in the partitive singular and inessive plural forms), and typical singletons (measured in the nominative plural forms).

Table 2 presents the average durations of the stem consonants in the four case forms. Since the consonant duration can be influenced by the word structure, we grouped the tokens by the structure of their weak grade stem (this structure is the same as in the genitive singular). Four groups were distinguished ${ }^{11}$ :

1) CVCV, e.g. kepi 'stick.GEN' (< keppi 'stick');

2) CVRCV, e.g. karpi 'box.GEN' (< karppi 'box');

3) CVVCV, e.g. kaapi 'wardrobe.GEN' (< kaappi 'wardrobe') or лauta 'cattle-shed.GEN' (< rauttâ 'cattle-shed');

4) CVCVCV, e.g. haraka 'magpie.GeN' (< harakka 'magpie').

For each of the four structures in Table 2, the first line (Average) presents the average duration of the consonant in milliseconds (ms), the second line (StDev) shows the standard deviation and the third line (N) indicates the number of pronunciations ${ }^{12}$. Figure 2 presents the average durations of the same consonants as a graph.

11 Here and below, $\mathrm{C}$ stands for a single consonant, $\mathrm{V}$ for a vowel, and $\mathrm{R}$ for a sonorant in a consonant cluster. $\mathrm{CC}$ denotes a geminate, and VV stands for a long vowel or diphthong.

12 The number of pronunciations is not exactly the same for the two speakers, because often a speaker would repeat the sentence several times. 
Table 2. Average durations and standard deviations (in ms) of the stem consonant in four morphological forms grouped by four stem structures

\begin{tabular}{|c|c|c|c|c|c|c|c|c|c|}
\hline \multirow{2}{*}{$\begin{array}{l}\text { Structure } \\
(\mathrm{GEN})\end{array}$} & & \multicolumn{4}{|c|}{ Speaker 1} & \multicolumn{4}{|c|}{ Speaker 2} \\
\hline & & PART & PL.INESS & INESS & PL.NOM & PART & PL.INESS & INESS & PL.NOM \\
\hline \multirow[t]{3}{*}{$\mathrm{CVCV}$} & Average & 211 & 201 & 166 & 100 & 193 & 173 & 160 & 88 \\
\hline & StDev & 43 & 27 & 22 & 23 & 41 & 31 & 19 & 15 \\
\hline & $\mathrm{N}$ & 39 & 31 & 44 & 41 & 48 & 47 & 52 & 45 \\
\hline \multirow[t]{3}{*}{ CVRCV } & Average & 154 & 152 & 143 & 98 & 162 & 145 & 153 & 95 \\
\hline & StDev & 30 & 31 & 14 & 15 & 27 & 22 & 28 & 16 \\
\hline & $\mathrm{N}$ & 14 & 15 & 12 & 12 & 18 & 17 & 16 & 13 \\
\hline \multirow[t]{3}{*}{ CVVCV } & Average & 183 & 172 & 150 & 98 & 170 & 180 & 153 & 94 \\
\hline & StDev & 26 & 23 & 16 & 23 & 31 & 41 & 25 & 16 \\
\hline & $\mathrm{N}$ & 17 & 14 & 29 & 21 & 23 & 19 & 31 & 25 \\
\hline \multirow[t]{3}{*}{ CVCVCV } & Average & 187 & 182 & 153 & 97 & 169 & 149 & 140 & 97 \\
\hline & StDev & 32 & 35 & 18 & 10 & 26 & 16 & 11 & 18 \\
\hline & $\mathrm{N}$ & 18 & 14 & 16 & 14 & 22 & 20 & 22 & 22 \\
\hline
\end{tabular}
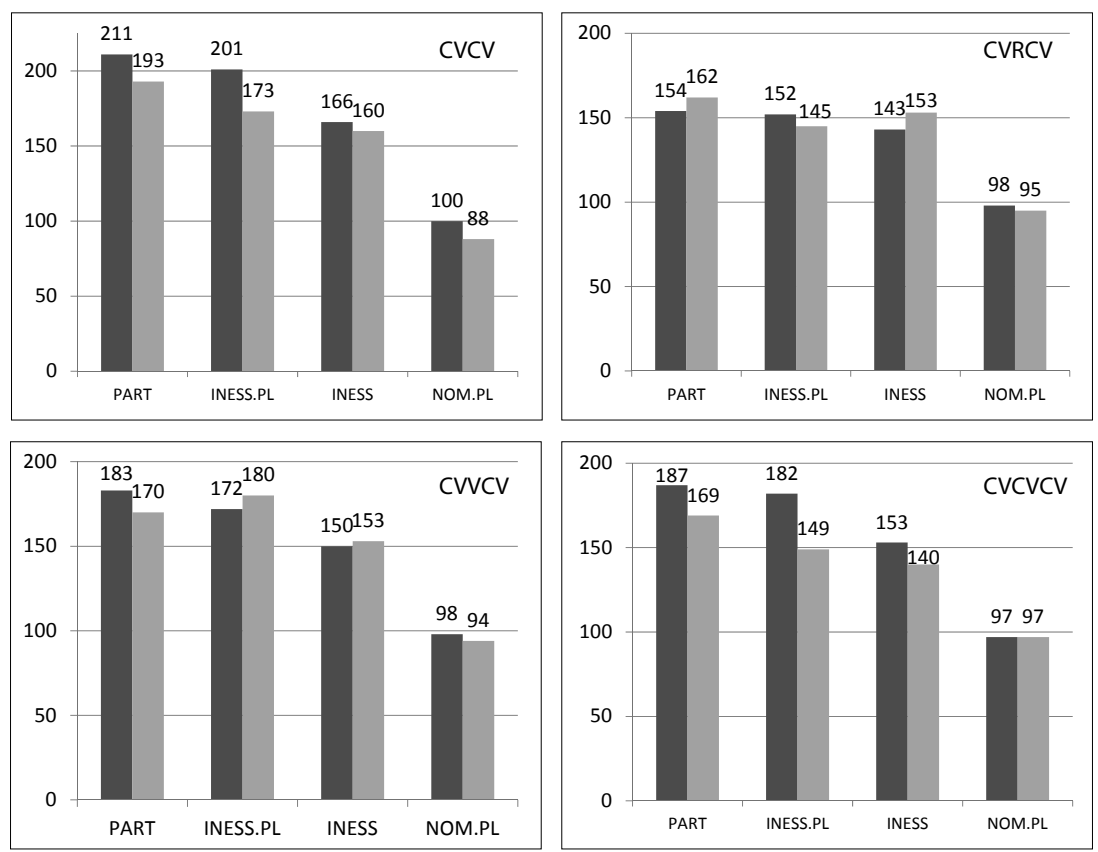

Figure 2. Durations of the stem consonant in the four case forms grouped by four structures. 
As seen from Table 2 and Figure 2, the consonant in the inessive singular is longer than in the nominative plural and shorter than in the partitive singular and the inessive plural (see also Table A-1 in the Appendix for the ratios of average durations). The only exception is the CVRCV structure for Speaker 2; here the consonant is longer in the inessive singular than in the inessive plural (153 vs. $145 \mathrm{~ms}$ respectively), but this difference is not statistically significant so their durations should be considered as similar.

An important conclusion here is that in most cases, the duration of the consonant in the inessive singular is somewhere in between the typical singletons and typical geminates. Thus, we achieved the same result in this controlled study as we had in the experiment based on the corpus data. It appears that the strong grade stem in the inessive contains a shorter geminate than other morphological forms. Most probably, this result explains the absence of the two peaks on the density curves (Figure 1).

Below we give a more thorough analysis of the results presented in Table 2 and Figure 2. We compare the inessive singular, first, with the nominative plural, and second with the strong grade forms, estimate the statistical significance of the observed differences, and offer some additional tests.

\subsubsection{Inessive singular vs. nominative plural}

The average duration of the single consonant in the nominative plural forms is very stable and does not depend on the stem structure of the form (see Table 2). For Speaker 1, it varies by no more than $3 \mathrm{~ms}$ $(97-100 \mathrm{~ms})$; for Speaker 2 it is almost the same in three structures (94-97 ms), and up to $9 \mathrm{~ms}$ less in the CVCV structure (88 ms). Compared to the inessive singular (143-166 ms for Speaker 1, 140-160 ms for Speaker 2), the nominative plural is 45 to $66 \mathrm{~ms}$ shorter for Speaker 1 , and 43 to $72 \mathrm{~ms}$ shorter for Speaker 2. The difference is always highly significant $(\mathrm{p}<0.001)$. This indicates that the consonant in the inessive forms analysed in this experiment is not a singleton.

Additionally, for a number of the test words the grade of the consonant in the inessive singular forms can be checked by examining the quality of the last syllable vowel. The words with the stem-final $a$ preserve this vowel in all forms that have the CVCV structure of the stem, 
in particular, the nominative plural and the inessive singular built from the weak grade stem (e.g. kukad 'flower.PL.NOM', kukaz 'flower.INESs'). If the inessive is built from a strong grade stem and therefore has the CVCCVC structure, the stem-final vowel changes into $e$ (historically it was a reduction process), e.g. kukkez 'flower.INEss'.$^{13}$ By checking the quality of the stem-final vowel ( $a$ vs. $e$ ), we can find out whether the preceding consonant is single or not.

We measured and compared the first formant of the second syllable vowel in two sets of forms: (1) the nominative plural in words with a CVCV stem structure and the stem-final a (kukad 'flower.PL.NOM', musad 'black.PL.NOM', rokad 'cabbage soup.PL.NOM', etsad 'edge. PL.NOM', vakad 'basket.PL.NOM', vatsad 'stomach.PL.NOM'); (2) the inessive singular of the same words. The results of this experiment are presented in Table $3^{14}$.

Table 3. Average values of $\mathrm{F} 1 \mathrm{(Hz})$ for the second vowel in the nominative plural vs. inessive singular forms, and the difference $(\Delta)$ between the values

\begin{tabular}{lcccccc}
\hline & \multicolumn{3}{c}{ Speaker 1 } & \multicolumn{3}{c}{ Speaker 2 } \\
\cline { 2 - 7 } & NOM.PL & INESS.SG & $\Delta$ & NOM.PL & INESS.SG & $\Delta$ \\
\hline Average F1 & 646 & 429 & 217 & 714 & 507 & 207 \\
N of tokens & 14 & 12 & & 13 & 12 & \\
\hline
\end{tabular}

It can clearly be seen that the vowel in the inessive singular forms is more closed than in the nominative plural forms (for both speakers, the difference in the F1 values is more than $200 \mathrm{~Hz}$ and it is highly significant, $p<0.001)$. This result confirms that the inessive forms analysed in this experiment do not have the CVCV structure of the stem; hence, their second consonant is not a singleton.

13 See the description of $a \sim e$ alternation and examples in Markus and Rožanskij (2017: 392-393) and Tsvetkov (2008: 22-27, 30-31).

14 See Markus and Rožanskij (2017: 630) for the whole space of Liivtšülä-Luuditsa Votic vowels. 


\subsubsection{Inessive singular vs. partitive singular and inessive plural}

The comparison of the inessive singular with two strong grade forms (the inessive plural and partitive singular) gives more ambiguous results. In Table 4, we show the difference in $\mathrm{ms}(\Delta)$ between the average durations of the stem consonant in the inessive singular vs. partitive singular and inessive singular vs. inessive plural (for two speakers). For each pair, the p-value shows the statistical significance of the difference between the two sets of tokens. See also Table A-1 in the Appendix for the ratios of average durations.

Table 4. Difference in the average duration (in $\mathrm{ms}$ ) of the stem consonant between the inessive singular, inessive plural, and partitive singular

\begin{tabular}{lccccc}
\hline & \multicolumn{3}{c}{ Speaker 1 } & \multicolumn{2}{c}{ Speaker 2 } \\
& & PART-INESS.SG & INESS.PL-INESS.SG & PART-INESS.SG & INESS.PL-INESS.SG \\
\hline CVCV & $\Delta$ & $\mathbf{4 5}$ & $\mathbf{3 5}$ & $\mathbf{3 3}$ & $\mathbf{1 3}$ \\
& $\mathrm{p}$ & $<0.001$ & $<0.001$ & $<0.001$ & $<0.05$ \\
\hline CVRCV & $\Delta$ & $\mathbf{1 1}$ & $\mathbf{9}$ & $\mathbf{9}$ & $\mathbf{- 8}$ \\
& $\mathrm{p}$ & $>0.05$ & $>0.05$ & $>0.05$ & $>0.05$ \\
\hline CVVCV & $\Delta$ & $\mathbf{3 3}$ & $\mathbf{2 2}$ & $\mathbf{1 7}$ & $\mathbf{2 7}$ \\
& $\mathrm{p}$ & $<0.001$ & $<0.001$ & $<0.05$ & $<0.01$ \\
\hline CVCVCV & $\Delta$ & $\mathbf{3 4}$ & $\mathbf{2 9}$ & $\mathbf{2 9}$ & $\mathbf{9}$ \\
& $\mathrm{p}$ & $<0.001$ & $<0.01$ & $<0.001$ & $>0.05$ \\
\hline
\end{tabular}

As seen from Table 4, neither speaker distinguishes the consonants in the inessive singular from the consonants in the two other forms $(p>0.05)$ if these consonants are part of a consonant cluster (the CVRCV structure ${ }^{15}$ ). However in all intervocalic positions, the consonant in the inessive singular is shorter than the consonants in the two other forms. For Speaker 1, this difference is highly significant $(\mathrm{p}<0.001)$ in all structures (only in trisyllabic words the difference between the inessive plural vs. singular has a p-value between 0.01 and $0.001)$. Speaker 2 does not oppose the forms so clearly. The statistical

15 The duration of the sonorant in the consonant cluster does not depend on a particular form. 
significance of the difference varies between highly significant for the partitive vs. inessive singular in CVCV and CVCVCV structures, significant for the inessive singular vs. plural in the CVVCV structure, possibly significant for the inessive singular vs. inessive plural in the CVCV structure and the partitive vs. inessive singular in the CVVCV structure, and not significant for the inessive singular vs. plural in the CVCVCV structure.

\subsubsection{Potential influence of the word structure}

The fact that the duration of the consonants in the inessive singular forms is not the same as in other strong grade forms needs an explanation. In this section, we check whether the shorter geminate in the inessive singular can be explained through the word structure. The strong grade inessive singular forms have a different segmental structure compared to the partitive singular (that ends in an open syllable), and the inessive plural (that has a diphthong in the last syllable), e.g. hattuz 'cap.INESS' - hattua 'cap.PART' - hattujz 'cap.PL.INESS'.

In order to check the effect of the open/closed final syllable, we compare the partitive singular and inessive plural forms. They have an identical structure (both have a diphthong in the final syllable), except that in the inessive plural the last syllable is closed (hattua 'cap.PART' hattujz 'cap.PL.INESS'). As seen from Table 2 and Figure 2, in most cases the geminate in the partitive singular is longer than in the inessive plural, the only exception being the CVVCV structure from Speaker 2. However, this difference is not statistically significant for Speaker 1 , and it is significant for Speaker 2 only in structures CVCV and CVCVCV $(0.001<p<0.01)$. This suggests that the open/closed status of the syllable is not a dominant factor defining the duration of the stem consonant.

Next, we check the correlation between the duration of the stem consonant and the duration of the surrounding vowels. In order to test this, we compare the inessive singular and inessive plural; the only difference between these forms is the short vowel vs. diphthong in the final syllable (hattuz 'cap.INESS' - hattujz 'cap.PL.INESS').

Figure 3 plots the pairwise duration of the analysed consonant (C), the preceding vowel (V1), and the following vowel (V2) in the inessive singular and inessive plural forms grouped by the four structures for the two speakers. 

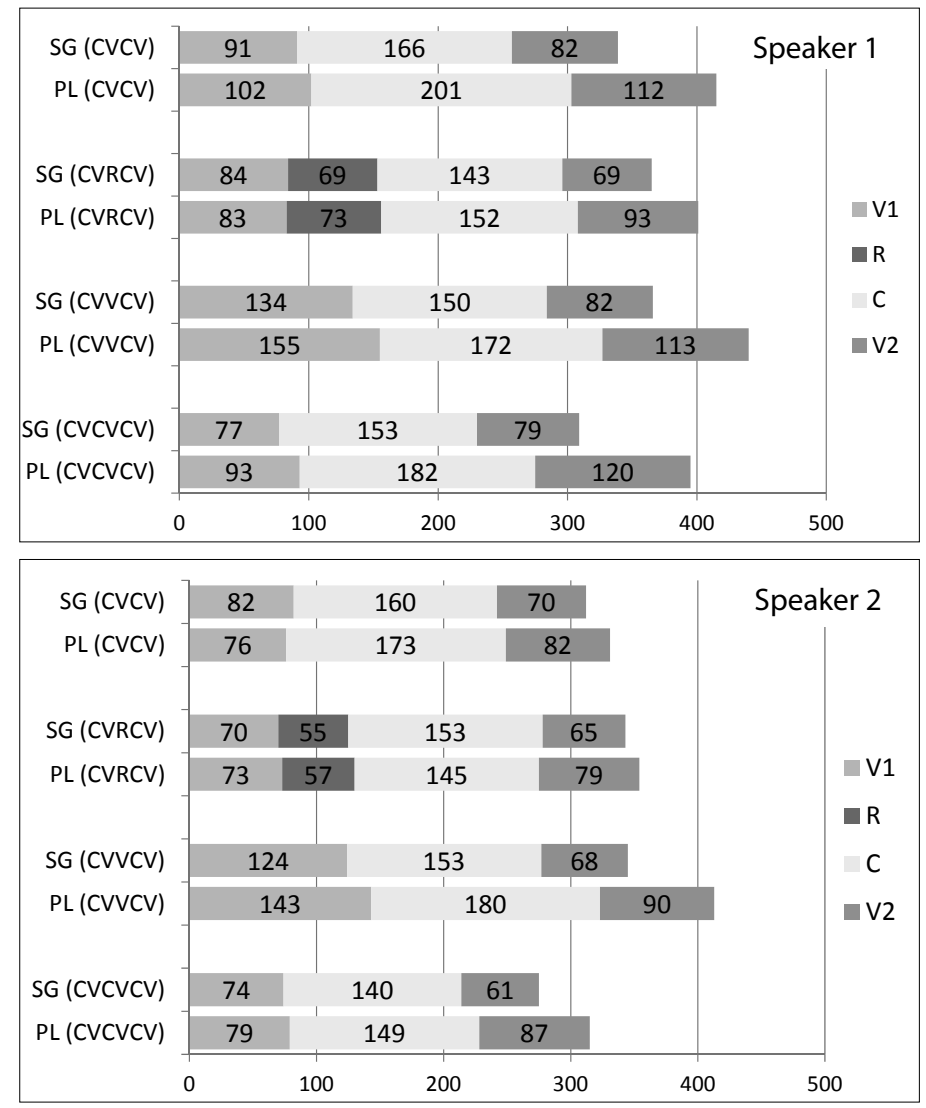

Figure 3. The duration of the consonant and the surrounding vowels (in $\mathrm{ms}$ ) in the inessive singular vs. inessive plural forms.

As seen from Figure 3, for Speaker 1 three of the recorded structures (CVCV, CVVCV, CVCVCV) have both the stem consonant and the preceding vowel (V1) shorter in the inessive singular than in the inessive plural. However, we cannot claim this as a general correlation. First, in the data from Speaker 2 the same tendency is clearly observed only in the structure CVVCV. In the CVCVCV structure, V1 is only $5 \mathrm{~ms}$ shorter in the inessive singular, and in the CVCV structure, V1 is even longer in the inessive singular compared to the inessive plural. Second, the difference between V1 in the inessive singular and plural is statistically significant only in the structure CVVCV $(\mathrm{p}<0.001$ for Speaker 1 and $\mathrm{p}<0.01$ for Speaker 2). 
The vowel following the stem consonant (V2) is phonologically different in the two analysed forms. In the inessive singular it is short, and in the inessive plural it is a diphthong. As seen from Figure 3 and Table 5, the diphthong is always longer than the short vowel. However, there is no strict correlation between the duration of the stem consonant and the duration of the following vowel. For example, for Speaker 2 the biggest difference between the duration of $\mathrm{V} 2$ in the inessive singular vs. plural forms ( $26 \mathrm{~ms}$, see Table 5) is found in the structure CVCVCV. In the same structure, the difference in the duration of the consonant is only $9 \mathrm{~ms}$ and it is not statistically significant (see Table 4). On the contrary, in the CVVCV structure the difference in the duration of V2 is smaller ( $22 \mathrm{~ms})$, but the difference between the consonant durations (27 ms) is statistically significant.

Table 5. The average duration (ms) of V2 and the difference $(\Delta)$ between the inessive singular and inessive plural forms

\begin{tabular}{lcccccc}
\hline & \multicolumn{3}{c}{ Speaker 1 } & \multicolumn{3}{c}{ Speaker 2 } \\
\cline { 2 - 7 } & INESS.PL & INESS.SG & $\Delta$ & INESS.PL & INESS.SG & $\Delta$ \\
\hline CVCV & 112 & 82 & 30 & 82 & 70 & 12 \\
CVRCV & 93 & 69 & 24 & 79 & 65 & 14 \\
CVVCV & 113 & 82 & 31 & 90 & 68 & 22 \\
CVCVCV & 120 & 79 & 41 & 87 & 61 & 26 \\
\hline
\end{tabular}

It appears that neither the duration of the preceding vowel nor the duration of the following vowel can explain the shorter geminate in the inessive singular forms.

\section{Discussion}

Experiments conducted in Section 3 revealed two facts:

1. Words with the alternation of geminates and single consonants can build the inessive singular forms both from the strong and weak grade stems (i.e. contain either a geminate or a single consonant in the last syllable).

2. In the inessive forms built from the strong grade stems, the geminate is often shorter than in other strong grade stems. 
Both these facts are not trivial and need an explanation. If a language has two types of geminates with significantly different durations, two theoretically possible approaches can be offered. One is to introduce a second type of geminates which are shorter than the regular geminates. For instance, in the neighbouring Soikkola Ingrian variety, there are full and short geminates. However, such an approach does not look promising in the case of Votic, because unlike in Soikkola Ingrian, there are no minimal pairs that confirm the phonological status of the two geminate types in Votic.

The second approach is to consider that geminates have two allophones, shorter and longer ones. Allophones that differ in duration often develop when the phonetic context changes. For example, the apocope of the final segment or adding a morphological marker can affect the duration of other segments in the form.

If we consider this kind of explanation, we need to discuss two hypothetical options. There are two phonetic processes that result in the change of the segment lengths in a word: (1) compensatory lengthening, and (2) change of length by analogy. In the first case, the shortening of a segment leads to the lengthening of a neighbouring segment and vice versa. It happens when a language has a tendency to preserve the length of a bigger unit, in particular the tendency to syllable or foot isochrony (see, for example, Krull (1999) on Estonian and Lehiste et al. (2008: 64-67) on Livonian). Compare, for example, the Estonian illative tuppa 'room.ILL' < *tupa-han from tuba 'room' where the geminate developed after the loss of the illative marker (Laanest 1975: 51). In the case of the Votic inessive, we do not see any compensatory effects: forms with a diphthong in the last syllable (the partitive singular and the inessive plural) have a longer geminate compared to the inessive singular that has a short vowel in the last syllable.

The change of length by analogy ${ }^{16}$ seems a more promising explanation. It corresponds to the distribution of lengths observed in the Votic inessive forms, because we find shorter geminates before short vowels in the inessive singular, and longer geminates before diphthongs in the

16 One of the most well-known examples of changing the length by analogy is secondary geminates in some Finnic languages. They developed from single consonants if the following vowel was long (or a diphthong), cf. Ingrian kala 'fish.NOM' and kallaa 'fish.PART' $(<*$ kalaa $)$. See more examples in Markus et al. (2013). 
inessive plural. Analogy might also explain the longer V1 in the inessive plural forms in several structures (see Figure 3), but apparently this lengthening is not consistent.

However, the explanation by analogy has at least two weak points. First, as shown in Section 3.2.3, we do not find a strict correlation between the duration of the stem consonant and the duration of the surrounding vowels. Second, we have no confirmation that the structure of the inessive singular (a strong grade stem plus a closed second syllable with a short vowel) causes a similar change of length in other morphological forms.

This structure is actually very rare in Liivtšülä-Luuditsa Votic, because most morphological cases have an open final syllable in the singular, cf. hattuz/hatuz 'hat.INESS' vs. hattu 'hat.NOM/ILL', hatu 'hat.GEN', hattua 'hat.PART', hatussô 'hat.ELAT', hatuллô 'hat.ADALL', hatuлtô 'hat. ABL', etc. In plural, all forms have a diphthong in the final syllable with the exception of the nominative plural that usually has a weak grade stem. In the contemporary verbal forms of the required structure (e.g. makkab 'sleep.PRs.3sG'), the short second vowel is a recent development $(<*$ makkaab), so they cannot be compared with the inessive singular.

The only morphological form that is structurally similar to the inessive singular form is the essive singular. It has a strong grade stem, and its marker has lost the final vowel: in the contemporary LiivtšüläLuuditsa variety, the essive is marked with $n$ that originates from *na/nä (Laanest 1975: 57). A consistent comparison of the inessive and essive forms is beyond our capacity, since the essive occurs only with a limited number of words (see more details in Markus and Rozhanskiy (2017). However, in our corpus there are some examples of the essive obtained from the same speakers we discussed above. Below (see Table 6), we analyze the essive forms of the nouns pappi 'priest' and seppo 'blacksmith' recorded from Speaker 1 (8 tokens) and Speaker 2 (11 tokens). Both nouns have genitive forms of the CVCV structure. The essive forms are pappin and seppen, respectively. The examples were elicited in the same way as the rest of the data; the target words were in sentence-final position. 
Table 6. The average duration (in $\mathrm{ms}$ ) of $\mathrm{V} 1, \mathrm{C}$, and $\mathrm{V} 2$ in the essive and inessive singular forms

\begin{tabular}{llrrrrrr}
\hline & & \multicolumn{3}{c}{ Speaker 1 } & \multicolumn{3}{c}{ Speaker 2 } \\
\cline { 3 - 8 } & & V1 & C & V2 & V1 & C & V2 \\
\hline \multirow{2}{*}{ Essive } & Average & 91 & 214 & 71 & 82 & 205 & 56 \\
& StDev & 14 & 22 & 15 & 20 & 32 & 10 \\
\hline \multirow{2}{*}{ Inessive } & Average & 91 & 166 & 82 & 82 & 160 & 70 \\
& StDev & 13 & 22 & 23 & 18 & 19 & 14 \\
\hline
\end{tabular}

As Table 6 shows, the duration of the consonant in the essive forms is significantly different from the inessive singular forms: 214 vs. 166 $\mathrm{ms}$ for Speaker 1, and 205 vs. $160 \mathrm{~ms}$ for Speaker 2. At the same time, the duration of geminates in other strong grade forms (the partitive singular and inessive plural, see Table 2) is much closer to the duration of geminates in the essive forms (211 and 201 vs. $214 \mathrm{~ms}$ for Speaker 1, 193 and 173 vs. 205 ms for Speaker 2).

The difference between the geminate duration in the inessive vs. essive forms cannot be explained through the different positions in the sentence. First, the position affects crucially the duration of the final vowel, but it does not influence the other segments as much. Second, if we assume an overall lengthening in sentence-final position, we would expect that $\mathrm{V} 1$ and $\mathrm{V} 2$ are longer in the essive forms as compared to the inessive. In fact, as seen from Table 6, no lengthening of the vowels is observed.

This experiment rejects the hypothesis that a shorter geminate in the inessive forms can be explained by the phonetic structure of the word. The inessive and essive singular forms have the same structure, but there is no rule that requires a shortening of the geminate.

The only hypothesis we can suggest to explain both the variation of stems and a shorter geminate in the strong stem is the influence of contact with the Ingrian language ${ }^{17}$. In Ingrian, the inessive forms are built from the weak grade stem, so words with a geminate in the nominative have a single consonant in the inessive, e.g. Soikkola Ingrian

17 Contact-induced prosodic changes have been attested in many languages, see e.g. Campbell and Muntzel (1989: 188), Hamp (1989: 204), Heath (1984: 372), Bodnarova and Wiedner (2015). 
keppi 'stick.NOM' - kebiž 'stick.INESs' ${ }^{18}$, kontti 'basket.NOM' - kondiiž 'basket.INEss', šöökki 'food.NOM' - šöögiiz 'food.INEss', Lower Luga Ingrian keppI 'stick.NOM' - kepiss 'stick.INESs', sü̈kkl 'food.NOM' süökiss 'food.InEss'. All the Votic speakers with whom we worked lived in villages with a mixed Votic-Ingrian population, so they were familiar with Lower Luga Ingrian to some extent. As the Ingrian influence on Vaipooli Votic is significant (Ariste 1981: 58-62), it might account for the variation of the strong (as in Votic) and weak stems (as in Ingrian). The speakers seem uncertain about which stem is better to use; we find variation even when the same form is repeated several times by the same speaker. This uncertainty might also account for the weakening of the geminate, so its lenght might have shortened.

The contact hypothesis explains the inconsistency in the description of the inessive by Tsvetkov (2008), because the Jõgõperä village had a mixed Votic-Ingrian population (Ariste 1981: 58, Muslimov 2005: 13). The weak stem in the inessive examples from the Central Votic varieties listed by Ahlqvist (1856) cannot be explained through language contact, since these varieties had no intensive contact with Ingrian ${ }^{19}$. The examples from Ahlqvist are rather mysterious considering that the weak stem in the inessive was not mentioned by Ariste (1968) who described the same varieties.

We think that most probably the variation in the inessive forms developed under the influence of several factors simultaneously. The processes that caused the variation developed in distinct ways in each variety, and happened in different time periods, though they could have partially overlapped. One should not exclude the fact that the Ingrian influence on the Vaipooli Votic varieties was an additional factor that added to the already existing instability in the inessive forms. Later, the Ingrian influence could become the main reason for variation, which gradually increased over the course of the 20th century.

Further research that could clarify the reasons behind the specific inessive forms in Votic should pay attention to published Votic texts.

18 In Soikkola Ingrian, voiced and unvoiced consonants are not phonologically opposed. A single consonant in the intervocalic position is usually pronounced as half-voiced or voiced (in the innovative idiolects).

19 In the case of Central Votic, one may consider the influence of the Finnish varieties it was in contact with, but we did not investigate this hypothesis. 
A detailed study of the inessive forms in all available texts could locate the emergence of the weak grade inessive more precisely, both from a dialectal and temporal perspective. However, one cannot be sure which variant of the transcription (a geminate or a single consonant) was chosen for pronunciations that were phonetically ambiguous. Thus, the phonetic reality behind the transcription would remain unclear.

It might also be helpful to look at data from the neighbouring languages. A strong grade stem in the inessive forms is not a unique Votic feature. It is found also in western Estonian dialects ${ }^{20}$. A detailed analysis of the inessive forms in these dialects (including an experimental phonetic study) could reveal some important similarities. However, it is difficult to estimate to what degree it can help to solve the Votic inessive problem. Even if similar effects were observed, a common origin of the phenomena is not likely, since the western Estonian dialects are geographically distant from Votic.

\section{Conclusions}

The research conducted in this paper showed that it is very typical for the speakers of the Liivtšülä-Luuditsa Votic variety to have a variation between strong and weak grade stems in the inessive singular forms. The geminate in the strong grade inessive singular appeared to be shorter than in other strong grade forms. Apparently, the shorter geminate is the reason why it is often difficult to perceptively define the grade of the consonant in the inessive singular forms.

We tested the effect of the word structure on the duration of the geminate, but found no certain reasons that could explain the shorter geminate in the inessive forms. The effect of the word structure was not confirmed, since the geminate is not shorter in the essive forms, although they have the same structure as the inessive singular.

It is probable that language contact with Ingrian played a role both in the spread of the variation between the weak and strong grade inessive, and the shortening of the geminate in the strong grade inessive.

20 Juhkam and Sepp (2000: 46) mention that the strong grade inessive is used in the Western and Insular dialect, as well as in the Mid dialect in its western part. See also the strong inessive isogloss in Pajusalu et. al (2002: 91). 
In Ingrian, the inessive is built from the weak grade stem. Since the Vaipooli Votic speakers lived in villages with mixed Votic-Ingrian populations and were familiar with Ingrian to some extent, mixing of the Votic and Ingrian patterns is likely.

The contact hypothesis explains the inconsistency in the description of the inessive forms by Tsvetkov (2008). However, the question of why the weak grade inessive forms are mentioned in the grammar by Ahlqvist (1856) needs further research.

\title{
Acknowledgements
}

We would like to thank the anonymous reviewer and Mehmed Muslimov for many valuable comments on the article, and Liina Lindström for consultation about the Estonian dialects. This research was supported by the University of Tartu, grant PHVEE18904.

\author{
Address: \\ Elena Markus \\ Institute of Estonian and General Linguistics \\ University of Tartu \\ Jakobi 2-409 \\ 51005 Tartu, Estonia \\ E-mail: helenmarkus@yahoo.com \\ Fedor Rozhanskiy \\ Institute of Estonian and General Linguistics \\ University of Tartu \\ Jakobi 2-410 \\ 51005 Tartu, Estonia \\ E-mail: handarey@yahoo.com
}

\begin{abstract}
Abbreviations
ABL - ablative, ADALL - adessive-allative, ELAT - elative, GEN - genitive, ILL - illative, INESS - inessive, NOM- nominative, PART - partitive, PL plural, SG - singular
\end{abstract}




\section{References}

Ahlqvist, August (1856) Wotisk grammatik jemte språkprof och ordförteckning. (Acta Societatis Scientiarum Fennicae, V: I.) Helsingfors.

Ariste, Paul (1942) "Vadja hälikute kvantiteedest". In Paul Ariste. Katselisfoneetilisi tähelepanekuid, 36-49. (Acta Universitatis Tartuensis / Dorpatensis B L.2.) Tartu.

Ariste, Paul (1962). Vadja muinasjutte. (Emakeele Seltsi Toimetised, 4.) Tallinn: Eesti NSV Teaduste Akadeemia.

Ariste, Paul (1968) A Grammar of the Votic language. (UAS, 68.) Bloomington and The Hague: Indiana University and Mouton \& Co.

Ariste, Paul (1981) Keelekontaktid. Eesti keele kontakte teiste keeltega. (Emakeele Seltsi Toimetised, 14.) Tallinn: Valgus.

Bodnarova, Zuzana and Jakob Wiedner (2015) "Analogical extension of vowel length in Vend Romani”. Acta Linguistica Hungarica 62, 2, 157-170.

https://doi.org/10.1556/064.2015.62.2.3

Boersma, Paul and David Weenink (2018) Praat: doing phonetics by computer [Computer program]. Version 6.0.37. Available online at $<$ http://www.praat.org/>. Accessed on 03.02.2018.

Campbell, Lyle and Martha C. Muntzel (1989) "The structural consequences of language death". In Nancy C. Dorian, ed. Investigating obsolescence: studies in language contraction and death, 181-196. Cambridge: Cambridge University Press. https://doi.org/10.1017/CBO9780511620997.016

Hamp, Eric P. (1989) "On signs of health and death". In Nancy C. Dorian, ed. Investigating obsolescence: studies in language contraction and death, 197-210. Cambridge: Cambridge University Press. https://doi.org/10.1017/CBO9780511620997.017

Heath, Jeffrey. G. (1984) "Language contact and language change". Annual Review of Anthropology 13, 367-384. https://doi.org/10.1146/annurev.an.13.100184.002055

Juhkam, Evi and Aldi Sepp (2000) Läänemurde tekstid. (Eesti murded, 8.) Tallinn: Eesti Keele Instituut.

Kettunen, Lauri (1930) Vatjan kielen äännehistoria. Toinen, uusittu painos. (Suomalaisen Kirjallisuuden Seuran Toimituksia, 185.) Helsinki: Suomalaisen Kirjallisuuden Seura.

Krull, Diana (1999) "Foot isochrony in Estonian". In John J. Ohala, ed. Proceedings of the XIVth international congress of phonetic sciences, 1063-1066. San Francisco: University of California.

Laanest, Arvo (1975) “Pribaltijsko-finskie jazyki”. In V. I. Lytkin, K. E. Majtinskaja, K. Redei, eds. Osnovy finno-ugorskogo jazykoznanija. Pribaltijsko-finskie, saamskij $i$ mordovskie jazyki, 5-122. Moskva: Nauka.

Lehiste, Ilse, Pire Teras, Valts Ernštreits, Pärtel Lippus, Karl Pajusalu, Tuuli Tuisk, and Tiit-Rein Viitso (2008) Livonian prosody. (SUST, 255.) Helsinki: SuomalaisUgrilainen Seura.

Markus, Elena, Pärtel Lippus, Karl Pajusalu, and Pire Teras (2013) “Three-way opposition of consonant quantity in Finnic and Saamic languages". In Eva Liina Asu and 


\section{Elena Markus and Fedor Rozhanskiy}

Pärtel Lippus, eds. Nordic prosody. proceedings of the XIth conference, Tartu 2012, 225-234. Frankfurt am Main: Peter Lang.

Markus, Elena and Fedor Rozhanskiy (2017) “The essive in Votic". In Casper de Groot, ed. Uralic essive and the expression of impermanent state, 91-112. (Typological Studies in Language, 119.) Amsterdam and Philadelphia: John Benjamins. https://doi.org/10.1075/tsl.119.04mar

Markus, Elena and Fedor Rožanskij (2017) Sovremennyj vodskij jazyk: teksty $i$ grammatičeskij očerk. 2-e izdanie, ispravlennoe i dopolnennoe. St. Petersburg: Nestor-Istorija.

Muslimov, Mexmed Z. (2005) Jazykovye kontakty v Zapadnoj Ingermanlandii (nižnee tečenie reki Lugi). Unpublished doctoral dissertation. Sankt-Peterburg: Institut lingvističeskih issledovanij RAN.

Pajusalu, Karl, Tiit Hennoste, Ellen Niit, Peeter Päll ja Jüri Viikberg (2002) Eesti murded ja kohanimed. Tallinn: Eesti Keele Sihtasutus.

Rozhanskiy, Fedor and Elena Markus (2015) "Dialectal variation in Votic: Jõgõperä vs. Luuditsa”. Journal of Estonian and Finno-Ugric Linguistics 6, 1, 23-39.

https://doi.org/10.12697/jeful.2015.6.1.02

Tsvetkov, Dmitri (1995) Vatjan kielen Joenperän murteen sanasto. (LSFU, XXV.) Helsinki: Suomalais-Ugrilainen Seura.

Tsvetkov, Dmitri (2008) Vadja keele grammatika. Tallinn: Eesti keele Sihtasutus. 


\section{Appendix}

In Table A-1, we give the ratios between the average durations of the stem consonant in six pairs: partitive singular vs. inessive singular, inessive plural vs. inessive singular, nominative plural vs. inessive singular, partitive singular vs. inessive plural, partitive singular vs. nominative plural, and inessive plural vs. nominative plural. The ratios are grouped by four stem structures for the two speakers (compare the absolute durations in Table 2).

Table A-1. Ratios between the average durations of the stem consonant grouped by four stem structures for the two speakers

\begin{tabular}{lcccccc}
\hline Structure & \multicolumn{3}{c}{ Speaker 1 } & \multicolumn{3}{c}{ Speaker 2 } \\
\cline { 2 - 7 } & $\begin{array}{l}\text { PART/ } \\
\text { INESS }\end{array}$ & $\begin{array}{c}\text { PL.INESS/ } \\
\text { INESS }\end{array}$ & $\begin{array}{c}\text { INESS/ } \\
\text { PL.NOM }\end{array}$ & $\begin{array}{c}\text { PART/ } \\
\text { INESS }\end{array}$ & $\begin{array}{c}\text { PL.INESS/ } \\
\text { INESS }\end{array}$ & $\begin{array}{c}\text { INESS/ } \\
\text { PL.NOM }\end{array}$ \\
\hline CVCV & 1.27 & 1.21 & 1.66 & 1.21 & 1.08 & 1.82 \\
CVRCV & 1.08 & 1.06 & 1.46 & 1.06 & 0.95 & 1.61 \\
CVVCV & 1.22 & 1.15 & 1.53 & 1.11 & 1.18 & 1.63 \\
CVCVCV & 1.22 & 1.19 & 1.58 & 1.21 & 1.06 & 1.44 \\
\hline & PART/ & PART/ & PL.INESS/ & PART/ & PART/ & PL.INESS/ \\
& PL.INESS & PL.NOM & PL.NOM & PL.INESS & PL.NOM & PL.NOM \\
\hline CVCV & 1.05 & 2.11 & 2.01 & 1.12 & 2.19 & 1.97 \\
CVRCV & 1.01 & 1.57 & 1.55 & 1.12 & 1.71 & 1.53 \\
CVVCV & 1.06 & 1.87 & 1.76 & 0.94 & 1.81 & 1.91 \\
CVCVCV & 1.03 & 1.93 & 1.88 & 1.13 & 1.74 & 1.54 \\
\hline
\end{tabular}


Kokkuvõte. Elena Markus ja Fedor Rozhanskiy: Vadja inessiivi mõistatus. Artiklis analüüsitakse ainsuse inessiivi morfofonoloogilist struktuuri Liivtšülä-Luuditsa vadja keeles. Selle keele soravaid kõnelejaid enam pole; uurimus põhineb 2003-2016 lindistatud materjalidel. Ainsuse inessiivi vormid näitavad nõrga- ja tugevaastmeliste tüvede varieerumist, mis on ühe käändevormi kohta väga ebatüüpiline. Kõikide teiste morfoloogiliste käänete puhul on nõrkade ja tugevate tüvede jaotus korrapärane. Inessiivi tüve varieerumist vaadeldakse nii varem avaldatud vadja keele allikates kui ka meie välitööde materjalides. Akustiline analüüs kinnitab tüvede varieerumist. Lisaks esineb tugevas astmes inessiivis lühem geminaatkonsonant või afrikaat kui teistes tugeva astme vormides (artiklis võrreldakse ainsuse inessiivi mitmuse inessiivi ja ainsuse partitiiviga). Me esitame mõned hüpoteesid, mis võiksid sellist varieerumist ja lühemat geminaati selgitada. Tehtud eksperimendid ei kinnita sõnastruktuuri rolli esmase faktorina geminaadi pikkuse defineerimisel. Me arvame, et nii tüvede varieerumine kui ka lühike geminaat võivad olla tingitud keelekontaktist. Naabruses olevates isuri murretes moodustatakse inessiiv nõrgaastmelisest tüvest. Kuna kõik viimased head vadja keele kõnelejad oskasid mingil määral isuri keelt, võisid vadja ja isuri keel olla segunenud. On tõenäoline, et algselt oli varieerumine tingitud teistest faktoritest, kuid keelekontakti suurenenud roll kujunes 20. sajandi jooksul domineerivaks.

Märksõnad: inessiiv, morfoloogia, morfofonoloogia, keelekontakt, eksperimentaalne foneetika, geminaat, varieerumine, vadja keel 